\title{
Anomalous enrichment of Mercury in early Cambrian in South China: \\ Implication for marine environment and biological evolution
}

Kun ZHAO ${ }^{1}$, GUANG-YOU ZHU ${ }^{1}$, TING-TING Li ${ }^{1}$, PENGJU WANG $^{1}$

${ }^{1}$ Research Institute of Petroleum Exploration and Development, PetroChina, Beijing 100083, China

The early The extensively deposited Early Cambrian black shale globally represents a significant global transgressive anoxic event, recording the synergistic changes in the marine environment and biological evolution. In order to reconstruction the Early Cambrian marine environment and atmospheric conditions, uses Danquan section of Youyang, Chongqing, South China as an example, to carry out the systematic research on the paleoclimate and marine environment of the Lower Cambrian Niutitang Formation. Through systematic analysis of $\mathrm{Hg}$ content, major and trace elements, and TOC, it was found that the black mudstone of Niutitang Formation is high in TOC content (5.53-12.00\%, average is $8.72 \%$ ) and rich in Mo, $\mathrm{U}, \mathrm{V}$, etc., and the $\mathrm{Hg}$ content is abnormally high (up to $6187 \mathrm{ppb}$, average is $3382.9 \mathrm{ppb}$ ). The relationship between $\mathrm{U} / \mathrm{Th}, \mathrm{V} / \mathrm{Cr}$, and $(\mathrm{Mo} / \mathrm{U} / \mathrm{V})_{\mathrm{EF}}$ indicates that the Niutitang Formation experienced a deposition process from anoxic sulphide (Interval I member) and anoxic ferruginous (Interval $\|$ member) from bottom to top; The abnormal enrichment of mercury content during the anoxic stage of ferruginous recorded the existence of high concentrations of gaseous $\mathrm{Hg}$ in the Early Cambrian atmosphere, which was related to the continuous volcanic eruption of the Cambrian. Therefore, the stratified marine environment and long-term high $\mathrm{Hg}$ atmospheric environment may be the important reasons that restrict the evolution of organisms and lead to the explosion of life in the Early and Middle Cambrian. 